\section{TRENDS IN WORLD MILITARY EXPENDITURE, 2019}

\author{
NAN TIAN, ALEXANDRA KUIMOVA, DIEGO LOPES DA SILVA,
} PIETER D. WEZEMAN AND SIEMON T. WEZEMAN

Global military expenditure is estimated to have been $\$ 1917$ billion in 2019, the highest level since 1988. The total was 3.6 per cent higher in real terms than in 2018 and 7.2 per cent higher than in 2010 (see figure 1). World military spending rose in each of the five years from 2015 , having decreased steadily from 2011 until 2014 following the global financial and economic crisis.

This Fact Sheet highlights the regional and national military expenditure data for 2019 and trends over the decade 2010-19. The data is from the updated SIPRI Military Expenditure Database, which provides military expenditure data by country for the years 1949-2019.

The world military burden-global military expenditure as a share of global gross domestic product (GDP)-in 2019 was 2.2 per cent, a minor increase from 2018. Military spending per capita rose from \$243 in 2018 to \$249 in 2019 , as the 1.1 per cent growth in the world population was surpassed by the growth in military spending.

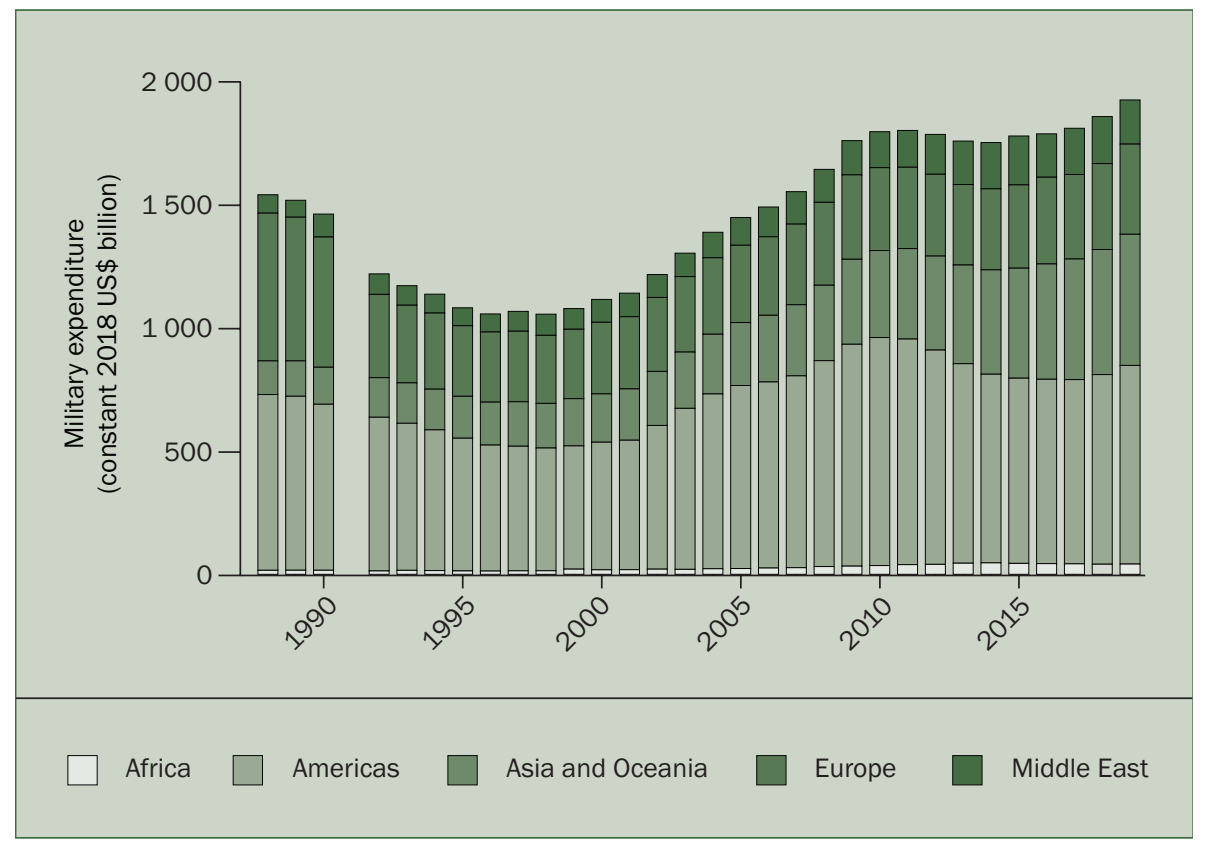

Figure 1. World military expenditure, by region, 1988-2019

Notes: The absence of data for the Soviet Union in 1991 means that no total can be calculated for that year.

Rough estimates for the Middle East are included in the world totals for 2015-19.

Source: SIPRI Military Expenditure Database, Apr. 2020.

\section{KEY FACTS}

- Global military expenditure was $\$ 1917$ billion in 2019, an increase of 3.6 per cent in real terms.

- Total military spending accounted for 2.2 per cent of global gross domestic product (GDP) in 2019.

- The five biggest spenders in 2019 were the United States, China, India, Russia and Saudi Arabia, which together accounted for 62 per cent of global military spending.

- US military spending grew by 5.3 per cent to $\$ 732$ billion. There were increases in military spending by China (5.1 per cent), India (6.8 per cent) and Russia (4.5 per cent). Spending fell in Saudi Arabia by 16 per cent.

- Military expenditure increased in Europe (5.0 per cent), Asia and Oceania (4.8 per cent), the Americas (4.7 per cent) and Africa ( 1.5 per cent). The total military expenditure of the countries in the Middle East for which data is available decreased by 7.5 per cent.

- The average military burden was 1.4 per cent of GDP for countries in the Americas, 1.6 per cent for Africa, 1.7 per cent for Asia and Oceania and for Europe and 4.5 per cent for countries in the Middle East for which data is available. 
Table 1. The 40 countries with the highest military expenditure in 2019

Spending figures and GDP are in US\$, at current prices and exchange rates. Changes are in real terms, based on constant (2018) US\$. Percentages below 10 are rounded to 1 decimal place; those over 10 are rounded to whole numbers. Figures and percentage shares may not add up to stated totals or subtotals due to the conventions of rounding.

\begin{tabular}{|c|c|c|c|c|c|c|c|c|}
\hline \multicolumn{2}{|l|}{ Rank } & \multirow[b]{2}{*}{ Country } & \multirow{2}{*}{$\begin{array}{l}\text { Spending (\$ b.), } \\
2019\end{array}$} & \multicolumn{2}{|c|}{ Change (\%) } & \multicolumn{2}{|c|}{ Spending as a share of GDP (\%) ${ }^{b}$} & \multirow{2}{*}{$\begin{array}{l}\text { World share (\%), } \\
2019\end{array}$} \\
\hline 2019 & $2018^{a}$ & & & $2018-19$ & 2010-19 & 2019 & 2010 & \\
\hline 1 & 1 & United States & 732 & 5.3 & -15 & 3.4 & 4.9 & 38 \\
\hline 2 & 2 & China & {$[261]$} & 5.1 & 85 & [1.9] & [1.9] & {$[14]$} \\
\hline 3 & 4 & India & 71.1 & 6.8 & 37 & 2.4 & 2.7 & 3.7 \\
\hline 4 & 5 & Russia & 65.1 & 4.5 & 30 & 3.9 & 3.6 & 3.4 \\
\hline 5 & 3 & Saudi Arabia & [61.9] & -16 & 14 & {$[8.0]$} & 8.6 & {$[3.2]$} \\
\hline \multicolumn{3}{|c|}{ Subtotal top 5} & 1191 & .. & .. & .. & .. & 62 \\
\hline 6 & 6 & France & 50.1 & 1.6 & 3.5 & 1.9 & 2.0 & 2.6 \\
\hline 7 & 9 & Germany & 49.3 & 10 & 15 & 1.3 & 1.3 & 2.6 \\
\hline 8 & 7 & United Kingdom & 48.7 & 0.0 & -15 & 1.7 & 2.4 & 2.5 \\
\hline 9 & 8 & Japan & 47.6 & -0.1 & 2.0 & 0.9 & 1.0 & 2.5 \\
\hline 10 & 10 & South Korea & 43.9 & 7.5 & 36 & 2.7 & 2.5 & 2.3 \\
\hline \multicolumn{3}{|c|}{ Subtotal top 10} & 1430 & .. & .. & .. & .. & 75 \\
\hline 11 & 11 & Brazil & 26.9 & -0.5 & 6.1 & 1.5 & 1.5 & 1.4 \\
\hline 12 & 12 & Italy & 26.8 & 0.8 & -11 & 1.4 & 1.5 & 1.4 \\
\hline 13 & 13 & Australia & 25.9 & 2.1 & 23 & 1.9 & 1.9 & 1.4 \\
\hline 14 & 14 & Canada & 22.2 & -2.0 & 27 & 1.3 & 1.2 & 1.2 \\
\hline 15 & 15 & Israel & 20.5 & 1.7 & 30 & 5.3 & 5.9 & 1.1 \\
\hline \multicolumn{3}{|c|}{ Subtotal top 15} & 1553 & .. & .. & .. & .. & 81 \\
\hline 16 & 16 & Turkey & 20.4 & 5.8 & 86 & 2.7 & 2.3 & 1.1 \\
\hline 17 & 17 & Spain & 17.2 & 0.9 & -7.1 & 1.2 & 1.4 & 0.9 \\
\hline 18 & 20 & Iran & 12.6 & -15 & -36 & 2.3 & 2.9 & 0.7 \\
\hline 19 & 21 & Netherlands & 12.1 & 12 & 9.8 & 1.3 & 1.3 & 0.6 \\
\hline 20 & 18 & Poland & 11.9 & 2.5 & 51 & 2.0 & 1.8 & 0.6 \\
\hline 21 & 22 & Singapore & 11.2 & 3.9 & 21 & 3.2 & 3.4 & 0.6 \\
\hline 22 & 23 & Taiwan & 10.4 & 1.1 & 1.9 & 1.7 & 2.0 & 0.5 \\
\hline 23 & 25 & Algeria & 10.3 & 7.8 & 93 & 6.0 & 3.5 & 0.5 \\
\hline 24 & 19 & Pakistan & 10.3 & 1.8 & 70 & 4.0 & 3.4 & 0.5 \\
\hline 25 & 24 & Colombia & 10.1 & 6.5 & 18 & 3.2 & 3.6 & 0.5 \\
\hline 26 & 28 & Kuwait & 7.7 & 4.7 & 48 & 5.6 & 3.8 & 0.4 \\
\hline 27 & 27 & Indonesia & 7.7 & -2.3 & 69 & 0.7 & 0.6 & 0.4 \\
\hline 28 & 31 & Iraq & 7.6 & 21 & 73 & 3.5 & 2.7 & 0.4 \\
\hline 29 & 30 & Thailand & 7.3 & 1.4 & 27 & 1.3 & 1.6 & 0.4 \\
\hline 30 & 29 & Norway & 7.0 & 4.7 & 30 & 1.7 & 1.5 & 0.4 \\
\hline 31 & 26 & Oman & 6.7 & -12 & 60 & 8.8 & 6.3 & 0.4 \\
\hline 32 & 32 & Mexico & 6.5 & 7.9 & 47 & 0.5 & 0.5 & 0.3 \\
\hline 33 & 34 & Sweden & 5.9 & 10 & 19 & 1.1 & 1.2 & 0.3 \\
\hline 34 & 33 & Greece & 5.5 & -0.4 & -23 & 2.6 & 2.7 & 0.3 \\
\hline 35 & 41 & Ukraine & 5.2 & 9.3 & 132 & 3.4 & 1.9 & 0.3 \\
\hline 36 & 35 & Chile & 5.2 & 0.3 & 11 & 1.8 & 2.2 & 0.3 \\
\hline 37 & 37 & Switzerland & 5.2 & 12 & 20 & 0.7 & 0.7 & 0.3 \\
\hline 38 & 40 & Romania & 4.9 & 17 & 154 & 2.0 & 1.3 & 0.3 \\
\hline 39 & 36 & Belgium & 4.8 & 3.4 & -7.3 & 0.9 & 1.1 & 0.3 \\
\hline 40 & 38 & Denmark & 4.6 & 4.2 & 8.1 & 1.3 & 1.4 & 0.2 \\
\hline \multicolumn{3}{|c|}{ Subtotal top 40} & 1771 & .. & .. & .. & . & 92 \\
\hline \multicolumn{3}{|c|}{ World } & 1917 & 3.6 & 7.2 & 2.2 & 2.5 & 100 \\
\hline
\end{tabular}

.. = data not available or not applicable; [] = SIPRI estimate; GDP = gross domestic product.

${ }^{a}$ Rankings for 2018 are based on updated military expenditure figures in the current edition of the SIPRI Military Expenditure Database. They may therefore differ from the rankings for 2018 given in SIPRI Yearbook 2019 and in other SIPRI publications in 2019.

${ }^{b}$ The figures for military expenditure as a share of GDP are based on estimates of 2019 GDP from the International Monetary Fund World Economic Outlook and International Financial Statistics databases.

Sources: SIPRI Military Expenditure Database, Apr. 2020; International Monetary Fund, World Economic Outlook Database, Oct. 2019; and International Monetary Fund, International Financial Statistics Database, Sep. 2019. 


\section{THE TOP 15 MILITARY SPENDERS IN 2019}

The top 15 military spenders in the world in 2019 were the same as those in 2018, but there were some significant changes in the rankings among the highest spenders (see table 1). Together, the top 15 countries spent $\$ 1553$ billion in 2019 , accounting for 81 per cent of global military expenditure.

All but three countries in the top 15 had higher military expenditure in 2019 than in 2010. The exceptions were the United States ( -15 per cent), the United Kingdom ( -15 per cent) and Italy ( -11 per cent). China's increase (85 per cent) was by far the largest among the top 15 .

Among the top 15 military spenders in 2019, Japan had the lowest military burden: it devoted only 0.9 per cent of its GDP to military expenditure. Saudi Arabia had the highest, 8.0 per cent. Among the top 15, the military burdens of Israel (5.3 per cent), Russia (3.9 per cent), the USA (3.4 per cent), South Korea (2.7 per cent) and India (2.4 per cent) were also higher than the global military burden.

With military expenditure of $\$ 732$ billion, the USA remained by far the largest spender in the world in 2019, accounting for 38 per cent of global military spending. The USA spent almost as much on its military in 2019 as the next 10 highest spenders combined (see figure 2).

US military expenditure was 5.3 per cent higher in 2019 than in 2018 (see table 1). This is the second year of growth in US military spending following seven years of continuous decline-between 2010 and 2017 spending fell by 22 per cent. The growth in the USA's military spending between 2017 and 2019 can be attributed to an increase in personnel costs from the recruitment of 16000 additional military personnel and the ongoing modernization of its conventional and nuclear weapon inventories. However, despite the recent increases, US military expenditure in 2019 remained 15 per cent lower than its peak in 2010 when the USA's military burden was 4.9 per cent of GDP.

China, the world's second-largest military spender, is estimated to have allocated $\$ 261$ billion to the military in 2019-equivalent to 14 per cent of global military expenditure. Its military spending in 2019 was 5.1 per cent higher than in 2018 and 85 per cent higher than in 2010. China's military expenditure has increased continuously since 1994 (for 25 consecutive years). The growth in its military spending has closely matched the country's economic growth. Between 2010 and 2019, China's military burden remained almost unchanged, at 1.9 per cent of its GDP.

The 6.8 per cent rise in India's military spending in 2019 in combination with the significant fall in Saudi

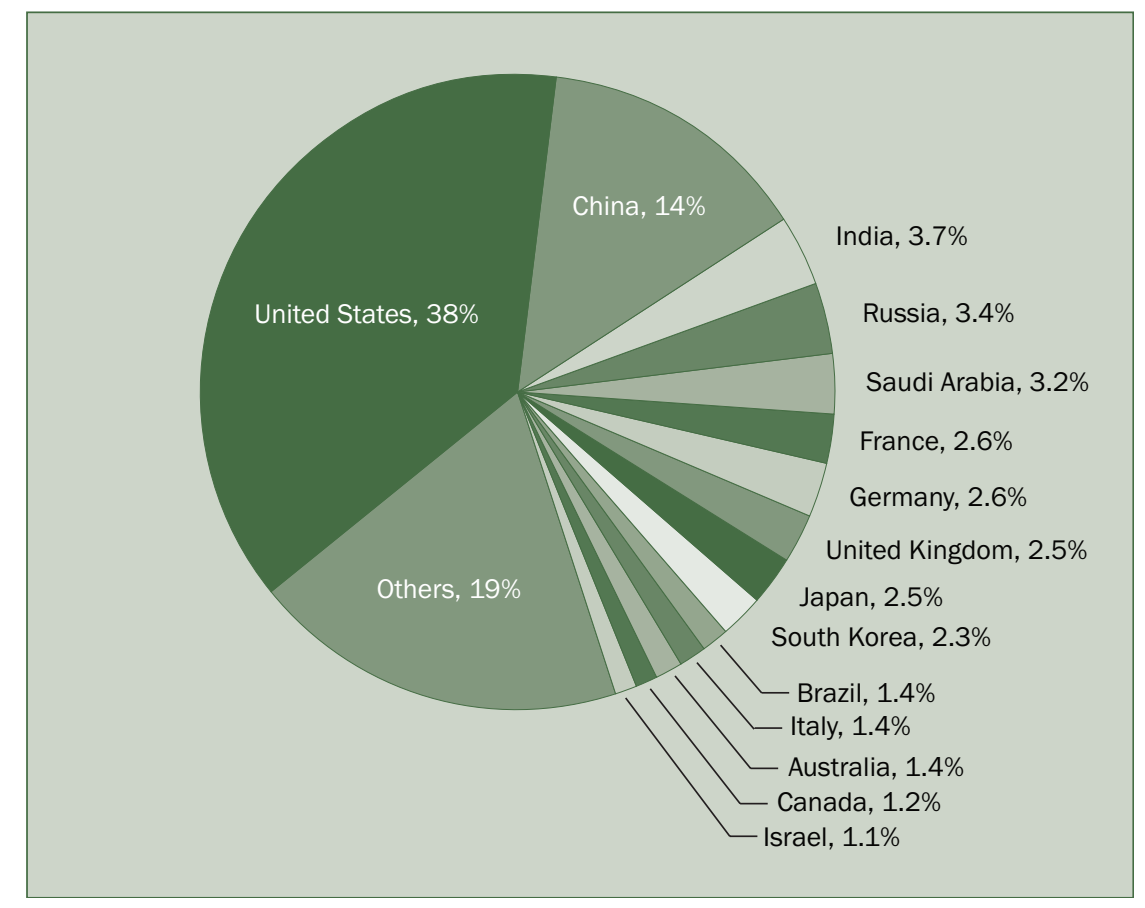

Figure 2. The share of world military expenditure of the 15 countries with the highest spending in 2019

Source: SIPRI Military Expenditure Database, Apr. 2020. 
Table 2. Military expenditure, by region and subregion, 2019

Spending figures are in US\$, at current prices and exchange rates. Changes are in real terms, based on constant (2018) US\$. Percentages below 10 are rounded to 1 decimal place; those over 10 are rounded to whole numbers. Figures and percentage shares may not add up to stated totals or subtotals due to the conventions of rounding.

\begin{tabular}{|c|c|c|c|c|}
\hline \multirow[b]{2}{*}{ Region and subregion } & \multirow{2}{*}{$\begin{array}{l}\text { Spending (\$ b.), } \\
2019\end{array}$} & \multicolumn{2}{|c|}{ Change (\%) } & \multirow{2}{*}{$\begin{array}{l}\text { World share (\%), } \\
2019\end{array}$} \\
\hline & & 2018-19 & 2010-19 & \\
\hline World & 1917 & 3.6 & 7.2 & 100 \\
\hline Africa ${ }^{a}$ & (41.2) & 1.5 & 17 & 2.1 \\
\hline North Africa & $(23.5)$ & 4.6 & 67 & 1.2 \\
\hline Sub-Saharan Africa ${ }^{a}$ & 17.7 & -2.2 & -15 & 0.9 \\
\hline Americas $^{b}$ & 815 & 4.7 & -13 & 43 \\
\hline Central America and the Caribbean ${ }^{b}$ & 8.7 & 8.1 & 49 & 0.5 \\
\hline North America & 754 & 5.1 & -15 & 39 \\
\hline South America & 52.8 & 0.2 & 8.9 & 2.8 \\
\hline Asia and Oceania ${ }^{c}$ & 523 & 4.8 & 51 & 27 \\
\hline Central Asia ${ }^{d}$ & 2.2 & 16 & 63 & 0.1 \\
\hline East Asia ${ }^{e}$ & 363 & 4.6 & 58 & 19 \\
\hline Oceania & 29 & 3.5 & 25 & 1.5 \\
\hline South Asia & 88.1 & 6.4 & 41 & 4.6 \\
\hline South East Asia $f$ & 40.5 & 4.2 & 34 & 2.1 \\
\hline Europe & 356 & 5.0 & 8.8 & 19 \\
\hline Central Europe & 31.5 & 14 & 61 & 1.6 \\
\hline Eastern Europe & 74.0 & 4.9 & 35 & 3.9 \\
\hline Western Europe & 251 & 3.9 & -0.6 & 13 \\
\hline Middle East ${ }^{g}$ & .. & .. &.. & .. \\
\hline
\end{tabular}

.. = data not available or not applicable; ()$=$ uncertain estimate.

${ }^{a}$ Figures exclude Djibouti, Eritrea and Somalia.

${ }^{b}$ Figures exclude Cuba.

${ }^{c}$ Figures exclude Myanmar, North Korea, Turkmenistan and Uzbekistan.

${ }^{d}$ Figures exclude Turkmenistan and Uzbekistan.

${ }^{e}$ Figures exclude North Korea.

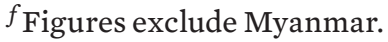

${ }^{g}$ No SIPRI estimate for the Middle East is available for 2015-19. A rough estimate for the Middle East (excluding Syria) is included in the world total.

Source: SIPRI Military Expenditure Database, Apr. 2020.

Arabia's spending (-16 per cent) over the same period meant that India ranked third in 2019 for the first time. Saudi Arabia's decrease and the increase in Russia's spending ( 4.5 per cent) meant that Russia moved up one place in the rankings, from fifth to fourth, while Saudi Arabia fell from third to fifth.

At $\$ 50.1$ billion, France's military spending in 2019 was the sixth highest in the world and the highest among states in Western Europe.

Germany had the highest annual increase (10 per cent) in military spending among the top 15 spenders in 2019 and moved up two places in the rankings, from ninth to seventh.

Six of the 15 highest spenders are members of the North Atlantic Treaty Organization (NATO): the USA, France, Germany, the UK, Italy and Canada. Together, these six accounted for 48 per cent ( $\$ 929$ billion) of global military expenditure. Total spending by all 29 NATO members was $\$ 1035$ billion in 2019. 


\section{REGIONAL TRENDS}

In at least four of the world's five regions, military expenditure increased in 2019 (see table 2). The highest increase was in Europe (5.0 per cent), followed by Asia and Oceania (4.8 per cent), the Americas ( 4.7 per cent) and Africa (1.5 per cent). For the fifth successive year, SIPRI cannot provide an estimate of total spending in the Middle East. Of the countries in the Middle East for which data is available, the combined military expenditure fell by 7.5 per cent in 2019.

\section{Africa}

At an estimated $\$ 41.2$ billion, military expenditure in Africa accounted for 2.1 per cent of the global total in 2019 (see table 2). The marginal growth in spending in 2019 was the first increase in African military expenditure for five years. Despite the annual decreases in 2015-18, increases in other years meant that total African military spending grew by 17 per cent over the decade 2010-19.

Military spending by countries in North Africa is estimated to have totalled $\$ 23.5$ billion in 2019, representing 57 per cent of the total for Africa. Amid long-standing tensions between Algeria and Morocco, domestic insurgencies and continuing civil war in Libya, military spending in the subregion was 4.6 per cent higher than in 2018 (see figure 3 ) and 67 per cent higher than in 2010.

Algeria's military expenditure of $\$ 10.3$ billion in 2019 was the highest in North Africa (and Africa as a whole) and accounted for 44 per cent of the subregional total. Algeria's military spending has risen almost continuously since 2000, and particularly in the period 2004-16, when expenditure grew for 13 consecutive years and reached an all-time high in 2016. At 6.0 per cent of its GDP, Algeria's military burden was the highest in Africa in 2019.

Military spending in sub-Saharan Africa fell by 2.2 per cent in 2019 to reach $\$ 17.7$ billion, which was 15 per cent lower than in 2010. At $\$ 3.5$ billion, South Africa's military spending was the highest in sub-Saharan Africa in 2019. Its spending fell by 1.5 per cent in 2019-the fourth consecutive year of decrease. Nigeria was the secondlargest spender in the subregion in 2019: it allocated $\$ 1.9$ billion to its military, down by 8.2 per cent compared with 2018 (see table 3).

In recent years spending on the military by sub-Saharan African states has been volatile. Of the 19 countries that increased military spending in 2019, 8 decreased spending in 2018. Similarly, 13 of the 23 countries that lowered

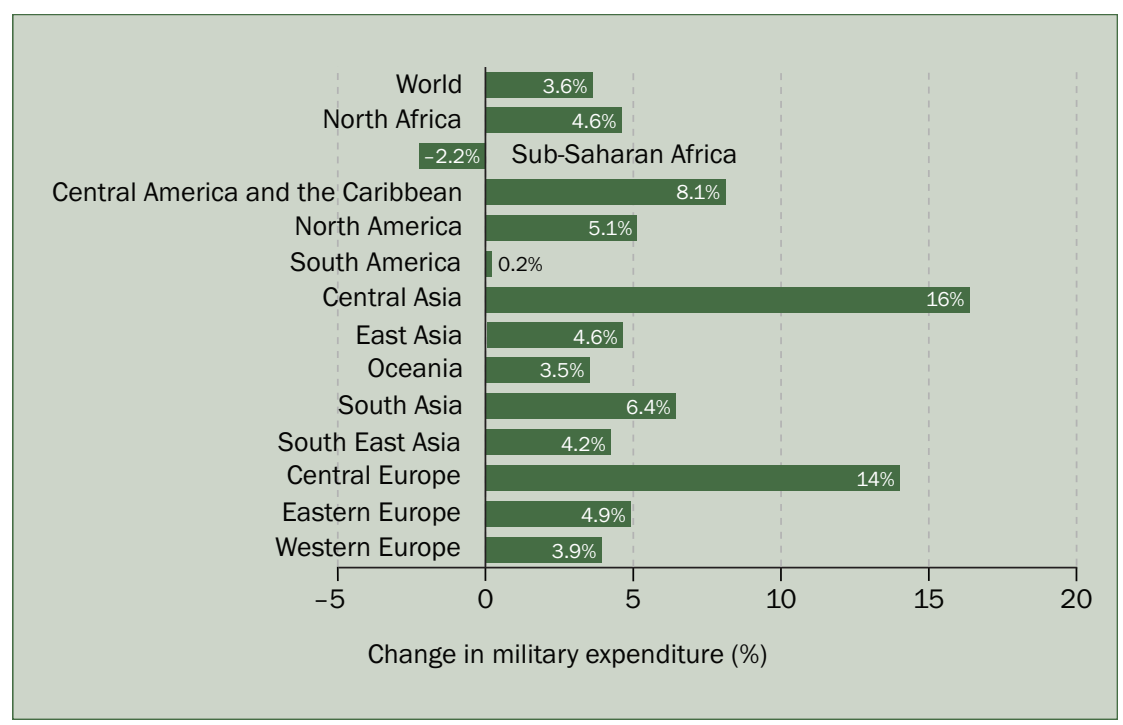

Figure 3. Changes in military expenditure, by subregion, 2018-19

Note: No estimate of change in military expenditure in the Middle East is given since data for 2015-19 is highly uncertain. However, an estimate for the Middle East is included in the estimated world total.

Source: SIPRI Military Expenditure Database, Apr. 2020. 
Table 3. The biggest relative increases and decreases in military expenditure, 2018-19

Spending figures are in US\$, at current prices and exchange rates. Changes are in real terms, based on constant (2018) US\$. Percentages below 10 are rounded to 1 decimal place; those over 10 are rounded to whole numbers. Countries with military expenditure in 2019 of less than $\$ 100 \mathrm{~m}$. (or $\$ 50 \mathrm{~m}$. in Africa) are excluded.

\begin{tabular}{|c|c|c|c|c|c|c|}
\hline Rank & Country & $\begin{array}{l}\text { Spending (\$ m.), } \\
2019\end{array}$ & $\begin{array}{l}\text { Increase (\%), } \\
2018-19\end{array}$ & Country & $\begin{array}{l}\text { Spending (\$ m.), } \\
2019\end{array}$ & $\begin{array}{l}\text { Decrease (\%), } \\
\text { 2018-19 }\end{array}$ \\
\hline 1 & Bulgaria & 2127 & 127 & Zimbabwe & 547 & -50 \\
\hline 2 & Togo & 171 & 70 & Mozambique & 137 & -22 \\
\hline 3 & Uganda & 646 & 52 & Benin & 68.1 & -20 \\
\hline 4 & Slovakia & 1865 & 48 & Niger & 172 & -20 \\
\hline 5 & Serbia & 1144 & 43 & Saudi Arabia & 61867 & -16 \\
\hline 6 & North Macedonia & 151 & 30 & Iran & 12623 & -15 \\
\hline 7 & Guatemala & 344 & 24 & Zambia & 293 & -13 \\
\hline 8 & Tunisia & 1001 & 23 & Lebanon & 2521 & -12 \\
\hline 9 & Burkina Faso & 358 & 22 & Oman & 6730 & -12 \\
\hline 10 & Iraq & 7599 & 21 & Bahrain & 1405 & -9.3 \\
\hline 11 & Jamaica & 252 & 20 & Argentina & 3143 & -9.2 \\
\hline 12 & Afghanistan & 227 & 20 & Sudan & 722 & -9.2 \\
\hline 13 & New Zealand & 2927 & 19 & Angola & 1471 & -8.7 \\
\hline 14 & Kazakhstan & 1766 & 19 & Nigeria & 1860 & -8.2 \\
\hline 15 & Brunei Darussalam & 415 & 17 & Côte d'Ivoire & 536 & -8.0 \\
\hline
\end{tabular}

Source: SIPRI Military Expenditure Database, Apr. 2020.

spending in 2019 had raised spending in 2018. This means that, overall, the trend in changes by 21 of the 42 countries in the subregion for which relevant data is available reversed in 2019.

Armed conflict is a major driver for the volatile nature of military spending in sub-Saharan Africa. For example, in the Sahel and Lake Chad region, where there are several ongoing armed conflicts, military spending increased in 2019 in Burkina Faso (22 per cent), Cameroon (1.4 per cent) and Mali (3.6 per cent) but fell in Chad ( -5.1 per cent), Niger ( -20 per cent) and Nigeria (-8.2 per cent). Among the Central African countries that were involved in armed conflict, military spending rose in 2019 in the Central African Republic (8.7 per cent), the Democratic Republic of the Congo (16 per cent) and Uganda (52 per cent) but fell in Burundi ( -4.5 per cent). In the Horn of Africa, military spending decreased in 2019 in Ethiopia (-1.6 per cent) and Kenya $(-1.7$ per cent); however, their spending in 2019 remained well above that in 2010: Ethiopia's was 12 per cent higher while Kenya's was 25 per cent higher.

\section{The Americas}

Military expenditure in the Americas reached \$815 billion in 2019 and accounted for 43 per cent of the global total. Three countries from the region were among the top 15 global spenders in 2019: the USA (rank 1), Brazil (rank 11) and Canada (rank 14). Despite the 4.7 per cent overall increase in 2019, military spending by states in the region was 13 per cent lower than in 2010. At $\$ 754$ billion, spending by the two countries in North America (Canada and the USA) accounted for 92 per cent of the total for the Americas. This was 5.1 per cent higher than in 2018 but 15 per cent lower than in 2010 (see table 2).

South America's military expenditure was relatively unchanged in 2019, at $\$ 52.8$ billion, up 0.2 per cent from 2018. This growth, albeit minor, continued 
an upward trend in military expenditure over the decade: between 2010 and 2019, spending grew by 8.9 per cent. In 2019 the three main contributors to South American military spending were Brazil (51 per cent), Colombia (19 per cent) and Chile ( 9.8 per cent). Together, they accounted for 80 per cent of the subregion's spending.

Brazilian military expenditure fell slightly in 2019, by 0.5 per cent, after two consecutive years of growth, to reach $\$ 26.9$ billion. Although the overall level of military expenditure remained relatively unaltered in 2019, important changes took place in spending categories. Personnel costs, for example, showed the largest annual increase in over a decade, as part of a plan to boost military salaries.

Total military expenditure by states in Central America and the Caribbean was $\$ 8.7$ billion in 2019. Military spending in the subregion increased by 8.1 per cent in 2019 and by 49 per cent over the decade 2010-19.

Mexico's military spending accounted for 75 per cent of the subregional total. At $\$ 6.5$ billion, it was 7.9 per cent higher than in 2018 . The growth was largely due to the costs associated with the government's strategy of using the military to combat drug cartels.

\section{Asia and Oceania}

Military spending in Asia and Oceania was $\$ 523$ billion in 2019 and accounted for 27 per cent of the global total (see table 2). Five of the top 15 global spenders in 2019 are in Asia and Oceania: China (rank 2), India (rank 3), Japan (rank 9), South Korea (rank 10) and Australia (rank 13).

The 4.8 per cent rise in the region's military spending in 2019 continued an uninterrupted upward trend dating back to at least 1989. Asia and Oceania is the only region with continuous growth since 1989 and the growth of 51 per cent over the decade $2010-19$ was by far the largest of any region. The increase was due primarily to the rise in Chinese military spending, which in 2019 accounted for 50 per cent of total spending in the region, up from 36 per cent in 2010.

There were substantial increases in all of Asia and Oceania's subregions between 2018 and 2019 and over the decade 2010-19 (see figure 3 and table 2). Over both periods, the highest level of increase was in Central Asia (63 per cent in 2010-19 and 16 per cent in 2018-19).

At $\$ 71.1$ billion, India had the highest military spending in South Asia in 2019. It was 6.8 per cent higher in 2019 than in 2018. India's military expenditure has risen significantly over the past few decades. It grew by 259 per cent over the 30-year period 1990-2019 and by 37 per cent over the decade 2010-19. However, its military burden fell from 2.7 per cent of GDP in 2010 to 2.4 per cent in 2019.

India's tensions and rivalry with China and Pakistan are among the major drivers for its increased military spending. Pakistan's own military expenditure rose by 70 per cent over the decade $2010-19$, to reach $\$ 10.3$ billion. Its military burden increased from 3.4 per cent of GDP in 2010 to 4.0 per cent in 2019.

In addition to China, Japan and South Korea are the largest military spenders in East Asia. Military spending by Japan was $\$ 47.6$ billion in 2019, 0.1 per cent lower than in 2018. Its spending increased by 2.0 per cent between 2010 and 2019. In South Korea the upward trend in military 
spending since 2000 continued. In 2019 its military spending reached $\$ 43.9$ billion, an increase of 7.5 per cent on 2018 and of 36 per cent on 2010.

Australia is by far the largest military spender in Oceania and its military expenditure in 2019 was $\$ 25.9$ billion. This was 2.1 per cent higher than in 2018 and 23 per cent higher than in 2010. Australia perceives heightened military threats in its neighbourhood, including from China, and globally.

Military spending in South East Asia increased by 4.2 per cent in 2019 to reach $\$ 40.5$ billion, after a 4.1 per cent fall in 2018. Over the decade 2010-19 spending increased by 34 per cent. Seven of the eight states in the subregion for which data is available increased their military spending between 2010 and 2019. The largest spenders in the subregion in 2019 were Singapore (28 per cent of the subregional total), Indonesia (19 per cent) and Thailand (18 per cent). For several states the increases in the past decade are partly to pay for expansion of the capabilities of their armed forces as a reaction to Chinese claims and activities in the South China Sea.

\section{Europe}

Total military spending in Europe in 2019 was $\$ 356$ billion, 5.0 per cent higher than in 2018 and 8.8 per cent higher than in 2010. Europe accounted for around 19 per cent of global military expenditure in 2019, making it the third-largest spending region after the Americas and Asia and Oceania. Five of the world's 15 largest military spenders are in Europe: Russia (rank 4), France (rank 6), Germany (rank 7), the UK (rank 8) and Italy (rank 12).

Box 1. Estimating military expenditure for Germany and the United Kingdom

There are differences in the definitions countries use for reporting on military expenditure. SIPRI has therefore adopted its own definition as a guideline (see 'The SIPRI Military Expenditure Database, sources and methods'). However, this means that there can be differences between SIPRI's estimates and the official data reported by countries. For example, SIPRI's annual estimates of military spending for Germany and the United Kingdom are significantly lower than the 'defence expenditure' figures that they report to the North Atlantic Treaty Organization (NATO). The gap between the SIPRI estimates for these countries and their NATO data has widened in recent years.

\section{Germany}

SIPRI's estimate of German military expenditure in 2019 is $\$ 3.3$ billion lower than the 'defence expenditure' figure Germany reported to NATO for that year. This is explained by the fact that the SIPRI total only includes spending by the German Ministry of Defence (MOD) and some minor spending on military activities by other ministries. In its 'defence expenditure' figure for NATO, Germany also includes spending on non-military efforts linked to sustaining peace and security, such as humanitarian and development aid in the context of crisis and peacebuilding and conflict resolution activities. However, the exact details of the German submission to NATO are confidential and it is therefore impossible to assess how much of the $\$ 3.3$ billion is accounted for by these non-military activities and whether it covers other unidentified military activities that are not included in the SIPRI total.

\section{United Kingdom}

SIPRI's estimate of the UK's military expenditure in 2019 is $\$ 11.2$ billion lower than the figure for 'defence expenditure' reported to NATO by the UK. The SIPRI figure is based on public data on expenditure by the British MOD. Other sources, including an assessment by the House of Commons covering 2017, indicate that between $\$ 3-4$ billion of the NATO figure might be attributable to military pension payments that are in addition to the reported expenditure by the MOD. These are not included in the SIPRI estimate because consistent spending data for the pension scheme could not be traced back for the entire data series. Other spending items that might be part of the UK's submission to NATO include the UK's contribution to United Nations peacekeeping operations and the cost of military operations not covered by the MOD budget. However, these additional expenditure items do not fully bridge the $\$ 11.2$ billion gap. Questions thus remain about what the British Government reports to NATO on its military expenditure. 
Military spending in Western Europe in 2019 was $\$ 251$ billion-up by 3.9 per cent on 2018 but down by 0.6 per cent on 2010. Military expenditure in Eastern Europe totalled $\$ 74.0$ billion in 2019. It was 4.9 per cent higher than in 2018 and 35 per cent higher than in 2010. All seven countries in Eastern Europe increased their military spending in 2019. In Central Europe spending in 2019 was $\$ 31.5$ billion-14 per cent higher than in 2018 and 61 per cent higher than in 2010.

France's military spending rose by 1.6 per cent in 2019 to reach $\$ 50.1$ billion. Over the decade 2010-19 its military spending increased by 3.5 per cent. The rise in 2019 followed the adoption of the Military Planning Law for 2019-25, which aims to bring France's spending on the military in line with the NATO target of 2 per cent of GDP by 2025 .

In 2019 Germany raised its military spending by 10 per cent to $\$ 49.3$ billion or 1.3 per cent of GDP (see box 1). Its military expenditure was 15 per cent higher than in 2010, when it was also 1.3 per cent of GDP. Notably, Germany's spending in 2019 was at the highest level since 1993, when the military burden was 1.7 per cent of GDP.

At $\$ 48.7$ billion, the UK's military expenditure was unchanged in 2019 but was 15 per cent lower than in 2010. The UK's spending has remained fairly stable since 2015 (see box 1). At 1.7 per cent of GDP, the UK's military burden in 2019 was at its lowest level since 1950.

Russia's military expenditure was $\$ 65.1$ billion in 2019 and accounted for 88 per cent of military spending in Eastern Europe. Russian military expenditure has grown significantly over the past two decades. By 2019, it was 30 per cent higher than in 2010 and 175 per cent higher than in 2000. Between 2018 and 2019, Russia's military spending increased by 4.5 per cent and its military burden rose from 3.7 per cent of GDP to 3.9 per cent.

Four countries in Central Europe increased their military spending by more than 150 per cent between 2010 and 2019: Lithuania (232 per cent), Latvia (176 per cent), Bulgaria (165 per cent) and Romania (154 per cent). Poland, which accounted for 38 per cent of the total for Central Europe in 2019 , increased its military spending by 51 per cent over the decade 2010-19. Between 2018 and 2019, Bulgaria had the highest relative increase in military spending of any country in the world (127 per cent; see table 3$)$. This spike in spending can be attributed to the full payment by Bulgaria for eight new combat aircraft ordered in 2019.

\section{The Middle East}

SIPRI has not estimated total military expenditure in the Middle East since 2015 because of a lack of data for Qatar, Syria, the United Arab Emirates (UAE) and Yemen. The combined total military expenditure in 2019 for the 11 countries for which data is available was $\$ 147$ billion. ${ }^{1}$

Two of the top 15 global spenders in 2019 are in the Middle East: Saudi Arabia (rank 5) and Israel (rank 15). Saudi Arabia is by far the largest military spender in the region, with an estimated total of $\$ 61.9$ billion in 2019. After military spending peaked at an all-time high in 2015, when Saudi Arabia was

\footnotetext{
${ }^{1}$ Countries included in the estimate are Bahrain, Egypt, Iran, Israel, Iraq, Jordan, Kuwait, Lebanon, Oman, Turkey and Saudi Arabia.
} 


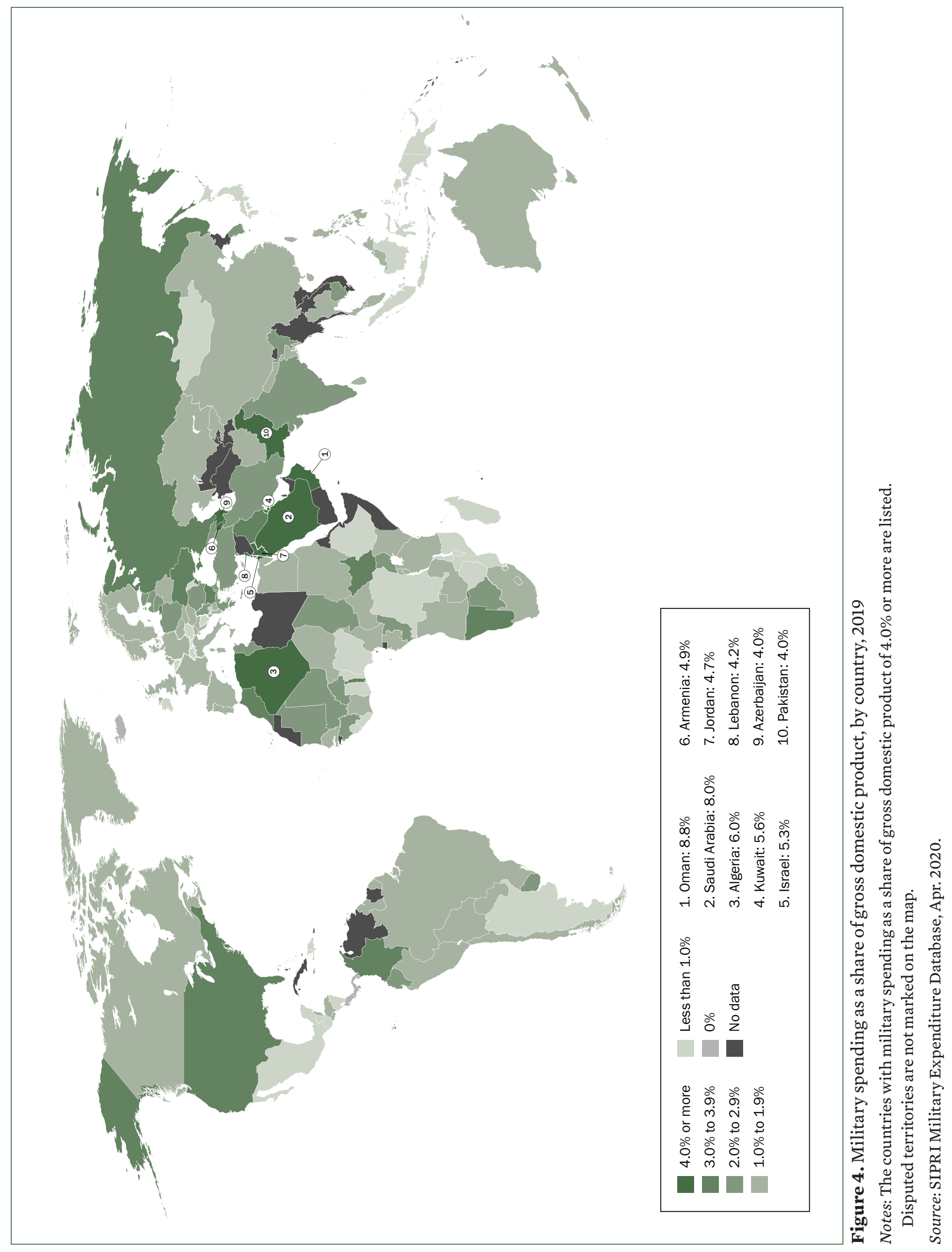


the third-largest military spender in the world, it dropped by 28 per cent in 2016, climbed by 15 per cent between 2016 and 2018, but decreased again in 2019 , by 16 per cent. The drop in military spending in 2019 was unexpected as Saudi Arabia continued its military operations in Yemen and, after a missile attack caused significant damage to its oil industry in September 2019, tensions with Iran increased.

Military spending by Israel was $\$ 20.5$ billion in 2019-a slight increase of 1.7 per cent compared with 2018. Between 2010 and 2019, Israeli military spending increased steadily, and in 2019 it was 30 per cent higher than in 2010.

Turkish military expenditure increased by 86 per cent over the decade 2010-19 to reach $\$ 20.4$ billion. There was a particularly steep increase in Turkish military spending between 2017 and 2018, of 27 per cent, while the increase between 2018 and 2019 was 5.8 per cent.

Iran's military expenditure in 2019 was $\$ 12.6$ billion, a decrease of 15 per cent compared with 2018. This followed a 23 per cent decrease in 2018. The fall in spending coincided with the Iranian economy being negatively affected by the USA's reinstatement of economic sanctions in early 2018 and occurred despite Iran's deteriorating relations with Saudi Arabia.

\section{MILITARY SPENDING AS A SHARE OF GDP}

A country's military expenditure as a share of GDP-also known as the military burden-is the simplest measure of the relative economic burden the military places on that country. The world military burden followed a declining trend in 2010-19, decreasing every year except for 2015 and 2019. There was substantial variation in the average military burden of each region over the decade: it decreased for countries in Africa and in the Americas, while it increased for countries in Europe and in the Middle East (for which data is available), and remained unchanged for countries in Asia and Oceania.

In 2019, on average, countries in the Americas had the lowest military burden, at 1.4 per cent of GDP. For African countries the average was slightly higher, at 1.6 per cent. In both Asia and Oceania and Europe it was 1.7 per cent. The highest average, 4.5 per cent, was for states in the Middle East for which data is available.

Of the 149 countries for which SIPRI has military burden data for 2019, 10 allocated 4.0 per cent or more of their GDP to the military, 13 had a military burden of 3.0-3.9 per cent of GDP, 24 had a military burden of 2.0-2.9 per cent, 65 had a military burden of 1.0-1.9 per cent, and 34 allocated less than 1.0 per cent of their GDP to the military (see figure 4). ${ }^{2}$ Three countries do not have a military and therefore have no military burden: Costa Rica, Iceland and Panama.

Six of the 10 countries with a military burden of 4.0 per cent or more are in the MiddleEast: Oman, which spent 8.8 per cent of its GDP on the military (the highest level in the world), Saudi Arabia (8.0 per cent), Kuwait (5.6 per cent), Israel (5.3 per cent), Jordan ( 4.7 per cent) and Lebanon ( 4.2 per cent). The other four are Algeria (6.0 per cent), Armenia (4.9 per cent), Azerbaijan (4.0 per cent) and Pakistan (4.0 per cent).

\footnotetext{
${ }^{2}$ No data on Somalia's GDP is available.
} 
SIPRI is an independent international institute dedicated to research into conflict, armaments, arms control and disarmament. Established in 1966, SIPRI provides data, analysis and recommendations, based on open sources, to policymakers, researchers, media and the interested public.

\section{GOVERNING BOARD}

Ambassador Jan Eliasson, Chair (Sweden)

Dr Vladimir Baranovsky (Russia)

Espen Barth Eide (Norway) Jean-Marie Guéhenno (France)

Dr Radha Kumar (India)

Ambassador Ramtane

Lamamra (Algeria)

Dr Patricia Lewis (Ireland/

United Kingdom)

Dr Jessica Tuchman Mathews

(United States)

\section{DIRECTOR}

Dan Smith (United Kingdom)

\section{The SIPRI Military Expenditure Database, sources and methods}

The SIPRI Military Expenditure Database provides military expenditure data by country for the years 1949-2019 in local current prices, constant US dollars, current US dollars, as a share of gross domestic product (GDP), per capita and as a share of general government expenditure. The SIPRI Military Expenditure Database was updated on 27 April 2020. This new data replaces all previous data published by SIPRI. The database and further details on the definitions, sources and methods used are available on the Military Expenditure Database web page of the SIPRI website.

All figures for spending in 2019 are given in 2019 current US dollars. Figures for relative increases or decreases in military spending-often described as changes in 'real terms' or adjusted for inflation-are expressed in constant (2018) US dollars.

\section{Sources}

SIPRI data reflects the official data reported by national governments. Such data is found in official publications such as budget documents. Of the 169 countries for which SIPRI attempted to estimate military expenditure in 2019 , relevant data was found for 150 .

\section{Definitions}

Where possible, SIPRI military expenditure data includes all current and capital expenditure on (a) the armed forces, including peacekeeping forces; $(b)$ defence ministries and other government agencies engaged in defence projects; (c) paramilitary forces, when judged to be trained and equipped for military operations; and (d) military space activities. This data should include expenditure on personnelwhich encompasses salaries of military and civil personnel and pensions and social services of military personnel-as well as expenditure related to operations and maintenance, procurement, military research and development, and military aid (in the military expenditure of the donor country).

Civil defence and current expenditure on previous military activities, such as veterans' benefits, demobilization, conversion, weapon destruction and military involvement in non-military activities (e.g. policing) are excluded.

The SIPRI military expenditure figures are presented on a calendar-year basis. The only exception is the United States, for which statistics report data on a fiscal-year basis. Calendar-year data is calculated on the assumption of an even rate of expenditure throughout the fiscal year.

\section{ABOUT THE AUTHORS}

Pieter D. Wezeman (Netherlands/Sweden) and Siemon T. Wezeman (Netherlands) are senior researchers with the SIPRI Arms and Military Expenditure Programme.

STOCKHOLM INTERNATIONAL PEACE RESEARCH INSTITUTE Signalistgatan 9 SE-169 72 Solna, Sweden Telephone: +4686559700 Email:sipri@sipri.org Internet: www.sipri.org
Diego Lopes da Silva (Brazil) and Nan Tian (China/South Africa) are researchers and Alexandra Kuimova (Russia) is a research assistant with the programme. 